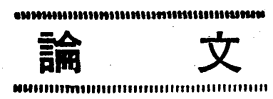

\title{
高温における低炭素鋼の引張繰返曲げ
}

\author{
動クリープと残留応力*
}

\author{
平 修二** 村上 裕 則*** 小寺 沢 良一**
}

\section{Dynamic Creep of Low Carbon Steel at Elevated Temperature as Related with the Residual Stresses Retained after Dynamic Creep under Combined Stresses of Static Tension and Alternating Bending}

by

\author{
Shuji TAIRA, Yasunori Murakami and Ryoichi KoterazawA \\ (Kyoto University) (Ritsumeikan University) (Kyoto University)
}

Dynamic creep tests were carried out with 0.05 percent carbon steel at $450^{\circ} \mathrm{C}$ under combined stresses of static tension and alternating bending. The present study aims to establish the basis for analysis of the dynamic creep strength under combined stresses of static tension and alternating bending from static creep data or from the data of dynamic creep under pulsating axial stresses: The residual stress retained after the dynamic creep test was measured and compared with the results of analysis, in order to examine the validity of the basic idea on which the analysis is based.

According to the results of the study, it is ascertained that the approximate estimation of the dynamic creep strength under combined stresses of static tension and alternating bending can be made by applying the same method of analysis as that for the prediction of dynamic creep under axial varying stress from static creep data, which has been reported previously: The distribution of the residual stress retained after the tests is also discussed.

(Received Jun. 2, 1959)

\section{1. 緒言}

高温において材料が静荷重と繰返荷重を同時に受け る場合のクリープについては, 多く静引張荷重のうえ に引張圧縮繰返荷重を重畳して加える引張圧縮動クリ 一プ試験が行なわれている．筆者らもこれについては 奉験的ならびに解析的研究を行なって，すでに低炭素 鋼および 13 クローム鋼について行なった実験の結果 から, 固体状態力学方程式を基礎として導き出した等 価静応力を使用することにより, 静クリープ試験結果 より動クリープ強度の推定が可能であることを示した。 しかし, 実際の機械部分はかならずしも引張圧縮変動 荷重のみを受けるのではなく，たとえば，タービン翼 は, 遠心力による静引張荷重と, 振動による繰返曲げ 荷重を同時に受ける.このような荷重状態における動 クリープについても筆者らはさきに 13 クローム鋼に ついて実験を行なった. 本報告は, 静引張クリープ試

* 原稿受付 昭和 34 年 6 月 2 日

** 正員 京都大学工学部

*** 正員 立命館大学理工学部
験結果から引張繰返曲げ動クリープ強度を推定するた めの解析的基礎を固めることを目的としたものであっ て, 引張王縮動クリープを取り扱う際に基本的な性質 を持つものとして取り上げた低炭素鋼の焼鈍材を使用 して, 実験と解析を行なうと同時に, その解析の基礎 とした考え方の妥当性を確かめる意味において, 試験 後の試験片に生ずる残留応力を测定して計算結果との 比較を行なったものである。

\section{2. 実験装置および実験方法}

本実験に使用した実験装置および実験方法は,ささ に 13 クローム鋼に関する実験に用いたと同一のもの である. 試験機は高温引張繰返曲げ疲労試験機で, 重 錘とレバーにより静引張荷重を与え, 偏心質量の回転 による強制振動によって定振幅繰返曲げを与える．振 幅測定はダイアルゲージとダッシュポットにより行な っている. 伸び測定は試験片標点距離の両端に取りつ けた取出棒の先端に直線の Edge を持つ薄板を付し, その相対移動を顕微鏡で読みとることにより行なった。 試験片の加熱には電気炉を使用し, 温度測定はアルメ 
Table 1 Chemical composition, heat treatment and mechanical properties at room temperature

\begin{tabular}{c|c|c|c|c|c|c}
\hline $\begin{array}{c}\text { Composi- } \\
\text { tion }\end{array}$ & $\mathrm{C}$ & $\mathrm{Si}$ & $\mathrm{Mn}$ & $\mathrm{P}$ & $\mathrm{S}$ & $\mathrm{Fe}$ \\
\hline$\%$ & 0.05 & 0.03 & 0.12 & 0.008 & 0.01 & bal. \\
\hline
\end{tabular}

Heated after machining at $920^{\circ} \mathrm{C}$ for one hour in vacuum with subsequent cooling in furnace

\begin{tabular}{c|c||c|c}
\hline $\begin{array}{c}\text { Yield point } \\
\left(\mathrm{kg} / \mathrm{mm}^{2}\right)\end{array}$ & $24 \cdot 1$ & $\begin{array}{c}\text { Elongation } \\
(\%)\end{array}$ & 36.0 \\
\hline $\begin{array}{c}\text { Tensile strength } \\
\left(\mathrm{kg} / \mathrm{mm}^{2}\right)\end{array}$ & 36.2 & $\begin{array}{l}\text { Reduction of } \\
\text { area }(\%)\end{array}$ & 71.3 \\
\hline
\end{tabular}

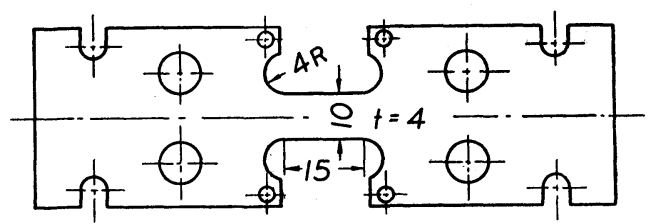

Fig. 1 Test specimen

ルクロメル熱電対と電位差計式温度計によっている。 また，サイラトロン方式の自動温度調整装置により， 試験片温度の時間的変動を $450^{\circ} \mathrm{C}$ において $\pm 2^{\circ} \mathrm{C}$ 以内 におさえた．残留応力の測定には腐食法を採用した。 すなわち, 試験片の一端固定, 他端に鏡を取りつけて, その片面を腐食し，この際生ずる鏡の回転を望遠鏡と スケールを用いて読みとり，その際の腐食量と読みの 変化の関係より残留応力を算出した.

\section{3. 試験材料および試験片}

試験材料は $0.05 \%$ 炭素鋼の焼鈍材であって，その 化学成分, 熱処理条件ならびに常温における機械的性 質を Table 1 に示す．低炭素鋼の焼鈍材を使用したの は，この種の材料については，すでに報告したように 組織的に安定で, 固体状態力学方 程式にもとづいた解析によって， 静クリープ試験結果から引張圧縮 動クリープ強度の推定が可能であ り,これについての実験ならびに 解析は他の材料の強度性質を解析 するための基礎を与えると考えら れるからである。試験片は厚さ $4 \mathrm{~mm}$, 幅 $10 \mathrm{~mm}$, 平行部分長さ $15 \mathrm{~mm}$ の板状試験片でその形状 寸法を Fig. 1 に示す. この試験 片の有効標点距離は既報の方法で 計算し, その值は $19.0 \mathrm{~mm}$ であ る.

4. 実 験 結 果

本実験における試験条件は

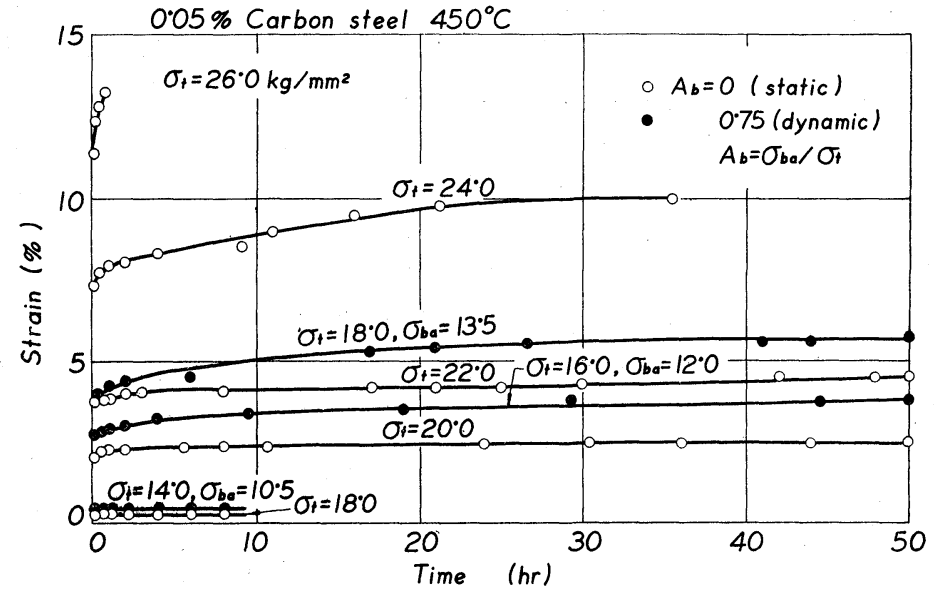

Fig. 2 The creep curves under static tension and the dynamic creep curves under combined static tensile and repeated bending stresses
Table. 2 Test conditions

\begin{tabular}{l|c}
\hline Temperature & $450^{\circ} \mathrm{C}$ \\
\hline $\begin{array}{l}\text { Stress } \\
\text { ratio }\left(\frac{\text { Repeated bending stress }}{\text { Static tensile stress }}\right) A_{b}\end{array}$ & $\begin{array}{c}0 \text { (Static) } \\
0.75 \text { (Dynamic) }\end{array}$ \\
\hline Frequency of repeated bending stress & $780 \mathrm{cpm}$ \\
\hline Duration of test & Up to 50 hours \\
\hline
\end{tabular}

Table 2 に示すとおりである.ここで応力比 $A_{b}$ は試 験片表面における最大繰返曲げ応力の静引張応力（静 引張荷重を断面積で除した公称值）に対する比である。 得られた実験結果を Fig. 2〜Fig. 5 に示す. Fig. 2, Fig. 3 は引張繰返曲げ動クリープ試験結果, Fig. 4, Fig. 5 は試験後の試験片に生じている残留応力の測定 結果である。

\section{(・I）引張綵返曲げ動クリープ試験結果}

Fig. 2 はクリープ曲線で, 白丸は静クリープ試験結 果, 黒丸が $A_{b}=0 \cdot 75$ における引張繰返曲げ動クリ一 プ試験結果である. Fig. 3 は Fig. 2 の結果を負荷後

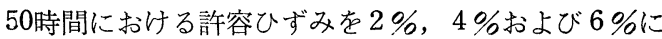
おさえた場合の静引張応力と繰返曲げ応力の組合せを 示す時間強度線図として表わしたものである。この図 において同一時間に同一ひずみを生ずる静引張応力は， 繰返曲げ応力の加わることによりかなり (20～25\%)減 少しており, 静引張応才坊ええに重畳して加えられた 繰返曲げ応力がかなりの程度にクリーブを促進するこ とを示している。

\section{(II) 残留応力測定結果}

材料が静引張応力と繰返曲げ応力を同時に受ける場 合，すでに報告したように，断面内における塑性変形 量が表面近傍と内部とでは異なるため, 平均応力の分 


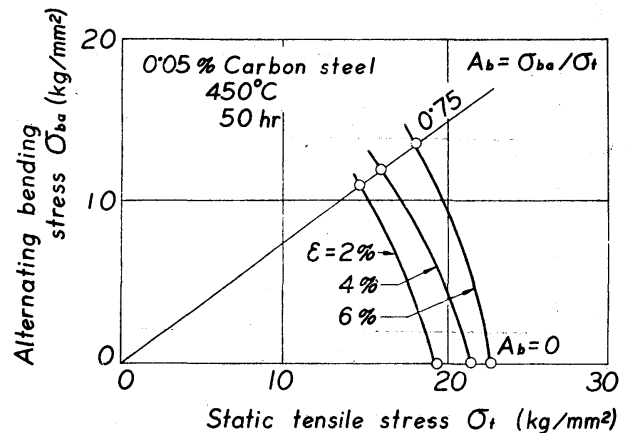

Fig. 3 Stress range diagram for specified creep strain (Combined static tensile and repeated bending stress)

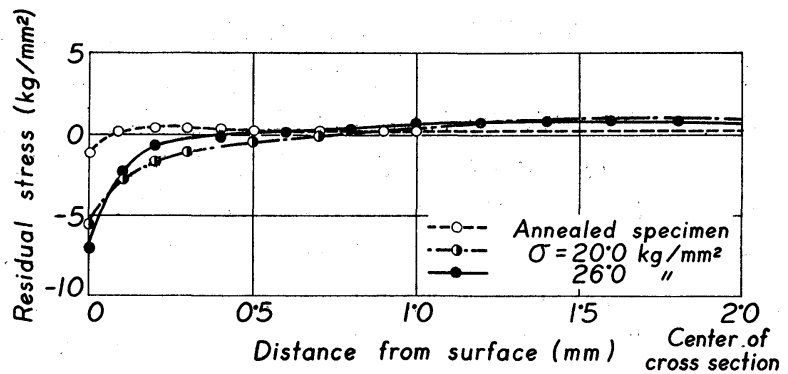

Fig. 4 Residual stresses in the annealed specimen and in those subjected to static creep tests

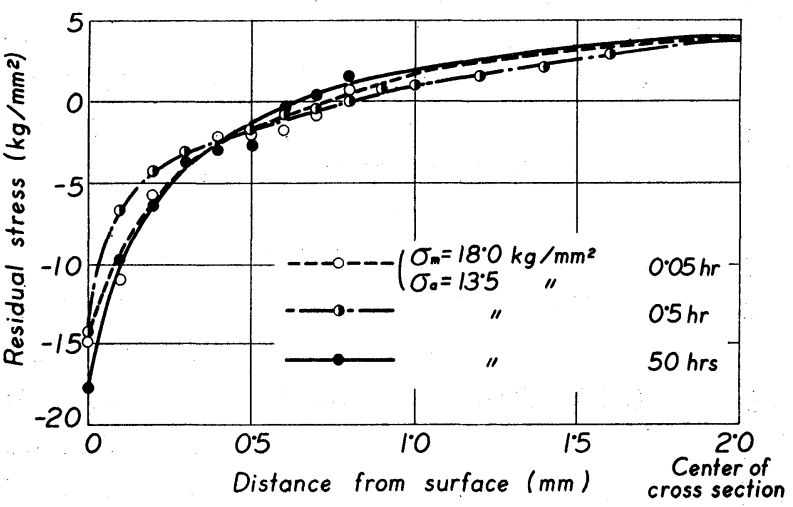

Fig. 5 Residual stresses in specimens subjected to dynamic creep test of combined static tension and repeated bending

布は一様でなく，大きい繰返応力の加わる表面におい て内部に比べて小さい平均応力の值を持つ結果として, 応力を取り去ったあとには表面に圧縮, 内部には引張 りの残留応力の発生することが予想される.すなわち， 引張繰返曲げ応力のもとにおける応力分布は, もし, 塑性变形(もしくはクリープ変形)がまったくおこらず 弾性変形のみであるとすると, Fig. 6 ( a )に示すよう に，一様な平均応力 $\sigma_{t}$ と断面中心において 0 で表面 に向かって直線的に増加する絽返応力（表面において

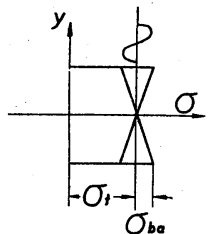

(a)

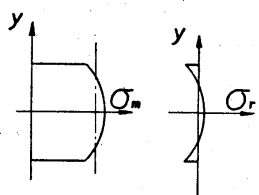

(b)

(c) $\sigma:$ Stress

$\sigma_{t}:$ Static tensile stress

$\sigma_{b a}:$ Alternating bending stress

$\sigma_{m}$ : Mean stress $\sigma_{r}$ : Residual stress

$y$ : Distance from the center of cross section

Fig. 6 Schematic representation of the cause of residual stress due to combined static tensile and repeated bending stresses

$\left.\sigma_{b a}\right)$ よりなる。したがって，表面に平行な 各層の受ける平均応力は同一であるが, 繰 返応力は中央では作用せず表面に近づくほ ど大きくなる。一般に平均応力に繰返応力 が加わることによりクリープひずみは増大 するものであるから，もし，これらの各層 が互に拘束されず自由に伸びうるものとす れば表面に近い層ほど伸びが大きくなるで あろう。しかし，実際は各層の間には拘束 があり, 变形前平面であった横断面は, 変 形後も平面を保つから, 表面には圧縮, 内 部には引張りの内部応力が発生し, 平均応 力の分布は Fig. 6 (b)に示すように表面 に近づくほど小さくなる。このような状態 より，外部から加えた応力を取り去ると

Fig. 6 （c）に示すように，表面に圧縮， 内部に引張りの残留応力が発生することと なる.Fig. 4 は焼鈍材および静クリープ試 験後の残留応力であり, Fig. 5 が問題とし ている引張繰返曲げ動クリープ試験後の残 留応力を示したものである。両図を比較す れば，うえで予想したように引張繰返曲げ 動クリープ試験後の試験片には焼鈍材およ び静クリープ試験後の試験片に比べていち じるしく大きい圧縮残留応力が試験片表面 において発生していることが認められる．うえの引張 繰返曲げ動クリープ試験後の残留応力測定結果は，負 荷後 3 分， 30 分および 50 時間後において行なったも のを示しているが，これらの間にほとんど羑異がなく， 上記内部応力は負荷後ごく短時間の間に定常状態に達 し，以後の変化はほとんどないことがわかる。なお，

Fig. 4 に示されているように静クリープ試験後に残留 応力が発生するのは主として表面効果によるものと推 測される。 


\section{5. 引張繰返曲げ動クリープの解析}

静クリープ試験結果から引張繰返曲げ動クリープ強 度の推定を可能ならしめるための解析を行なうのが本 節の目的であるが, 静クリープ試験結果から引張圧縮 動クリープ強度を推定する方法についてはすでに報告 したとおりであるので,ここでは引張圧縮動クリープ 強度が与えられた場合にこれから引張繰返曲げ動クリ 一プ強度を計算する方法について考える。，そのために はまず，前節で述べた平均応力の分布を求めなければ ならない，前節で述べたように，試験片表面に平行な 各層は互に拘束されているために自由に伸びえず，試 験片断面は平面を保持する。これがこの際与えられた 一つの条件となる。絽返曲げのために各層のひずみは 周期的に変動しているが，その振幅の中心位置へきた ときを考えると，そのときの各層の全ひずみならびに その增加速度は上記条件によって断面全体にわたって 一定でなければならない. 全ひずみは弾性ひずみとク リープひずみからなり，弾性ひずみは平均応力の不均 一な分布に伴なって一定でないから，クリープひずみ も厳密には一定でない，しかし，いまの場合，クリー プがいちじるしいために全ひずみの中の弾性ひずみの 割合はきわめて小であって，ひずみはほとんどクリー プひずみのみとみなしてさしつかえない。したがって， クリープひずみもクリープひずみ速度とともに断面全 体にわたって近似的に一定となる，ところで筆者らは 静クリープ試験結果から引張圧縮動クリープ強度を推 定する際に、「等価静応力」を使用しているが, これの 定義はある变動応力のもとにおけるクリープひずみと 等しいクリープひずみを与える静応力である。したが って，上記クリープひずみならびにクリープひずみ速 度が断面内において一様であることは，とりもなおさ ず等価静応力が断面全体にわたって一定であることに ほかならない。

等価静応力は与えられた材料についてある温度のも とにおいては平均応力と応力振幅の関数である. 本実 験では定振幅の繰返曲げを与えているためにひずみ振 幅が与えられた条件であって，断面中心で 0 で表面に 向かって直線的に増加する．繰返曲げ応力の繰返速度 がかなり大きいからその間の変形はほぼ弾性的とみな され，ひずみ振幅に弾性係数を乗ずることによって応 力振幅は既知となる.したがって, 等価静応力一定の条 件より，与えられた $\sigma_{a}$ の断面内分布に対して $\sigma_{m}$ の 分布が定まる。 $\sigma_{m}$ の分布が定まればこれをむととし て引張圧縮動クリープ強度と引張繰返曲げ動クリープ 強度の関係を求めることができる，その方法はつぎの とおりである。

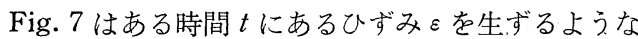
平均応力 $\sigma_{m}$ 之応力振幅 $\sigma_{a}$ の組合せを示す時間強度

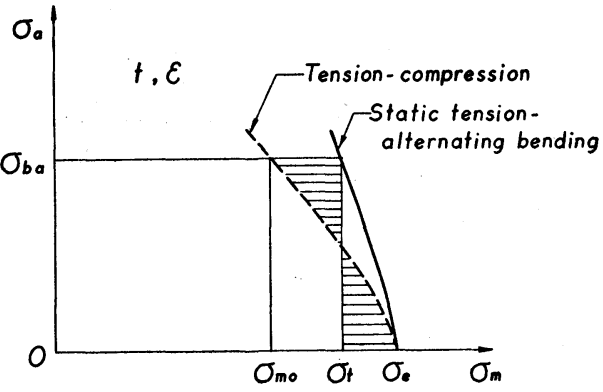

Fig. 7 Schematic representation of stress range diagram for combined static tension and repeated tension and for combined static tension and repeated bending

線図を模型的に表わしたもので，破線で示した引張圧 縮の場合の線図が求まっているものとする。これをも ととして, かりに実線で表わした引張繰返曲げの場合 の $\sigma_{t}$ と $\sigma_{b a}$ の関係を示す線図を求めるのがここにお ける問題である. いま, 任意の $\sigma_{b a}$ に対して $t$ 時間に ひずみ をを生ずるような $\sigma_{t}$ を求めることを考える. $\sigma_{b a}$ は試験片表面における応力振幅であるから, 試験 片表面における平均応力は引張圧縮動クリープに関す る破線上の $\sigma_{b a}$ に対応する $\sigma_{m}$ すなわち $\sigma_{m 0}$ で与えら れる、破線上では等価静応力 $\sigma_{e}$ は一定であり, 横軸 上では応力振幅は 0 であるから, 破線と横軸の交点に おける $\sigma_{m}$ がこの場合の断面全体について一定な $\sigma_{e}$ の值を与える. また, 応力振幅は断面中心で 0 で断面 内で直線的分布を持つから, 図の縦座標 $\sigma_{a}$ は断面中 心よりの距離に比例することとなり，破線がこの際の 断面内の平均応力の分布を与える.したがって,この平 均応力の断面についての平均が $\sigma_{t}$ となる. 本実験の 場合は板の平面曲げであるから, 図のうえでの平均す なわち, 図中のハッチを施した二つの部分の面積が等 しくなるように引いた横軸への垂線が $\sigma_{t}$ の值を与え る.また，引張荷重を除いたあとの中立軸の片側の残 留応力の分布は八ッチを施した部分によって示される ものである。このようにして引張繰返曲げに対する $\sigma_{b a}-\sigma_{t}$ 線図上の一点が求められたから, 同じことを 繰り返すことにより実線で表わした線図が求まる。

Fig. 8 は前述の引張繰返曲げ動クリープ試験結果と解 析結果を両軸に静引張応力および繰返曲げ応力の等価 静応力に対する比をとって無次元表示した時間強度線 図上において比較したものである，破線が静クリープ 試験結果より計算した引張圧縮動クリープに関する線 図で, これより, 上記方法で引張繰返曲げの場合の計 算を行なった結果が実線で示した曲線である。太だし， ここで静クリープ曲線を，

$$
\varepsilon=a \sigma^{\alpha} t^{\beta}
$$




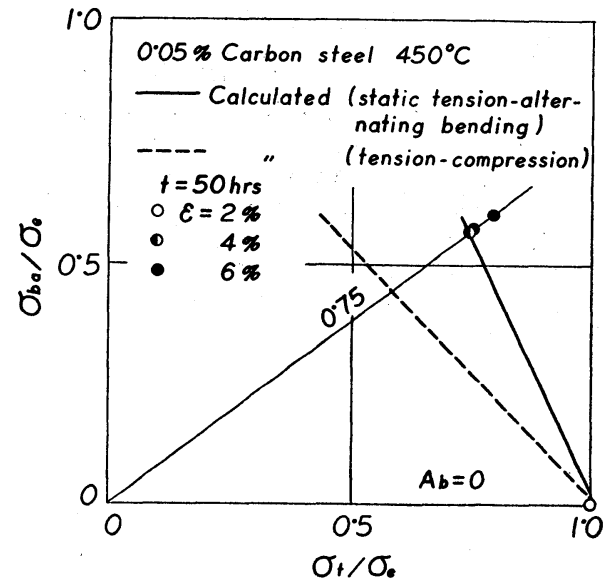

Fig. 8 Non-dimensional stress range diagram of a low carbon steel for the combined static tension and repeated bending (The line for the combined static and repeated tension is presented for reference)

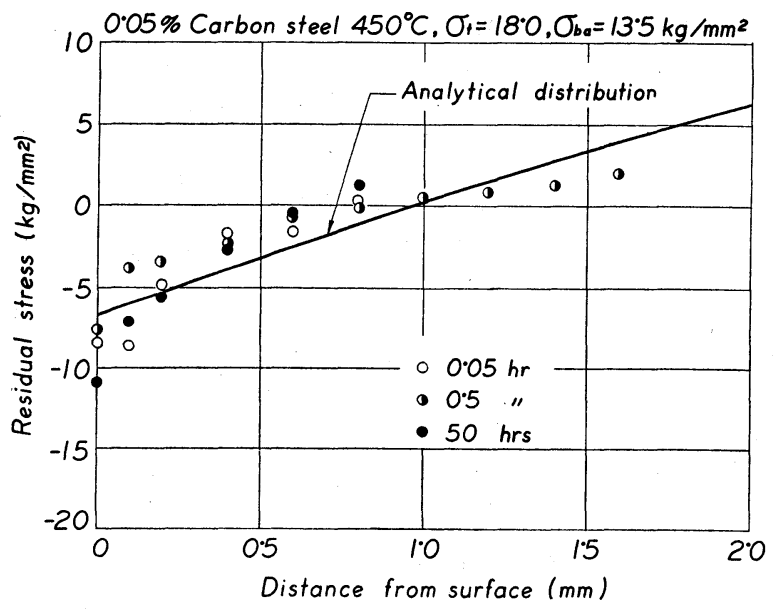

Fig. 9 Comparison of analytical distribution of residual stress with experimental one

$$
\begin{aligned}
& \varepsilon: \text { クープひずみ, } \sigma: \text { 応力, } t: \text { 時間, } \\
& a, \alpha, \beta: \text { 定数 }
\end{aligned}
$$

なる式で近似して求めた $\alpha / \beta=97$ を用いて計算を行 なっている，実線で表わした引張繰返曲げ動クリープ 強度の計算結果は丸印で示した実験結果とまず満足す べき一致を示しているといえる. Fig. 9 は残留応力の 実験值と計算值の比較である. 縦軸の残留応力として は, Fig. 5 の引張繰返曲げ動クリープ試験後の残留応 力より, Fig. 4 の静クリープ試験後の残留応力をさし 引いたものが繰返曲げにより発生したものと考えて， これをとって実線の計算值と比較している.両者の間 に多少の相違はあるが，ほぼ近い值を与えており，引

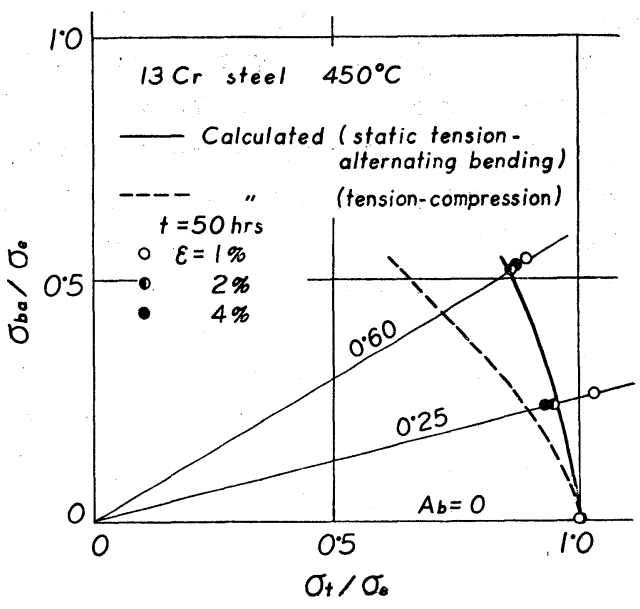

Fig. 10 Non-dimensional stress range diagram of 13 chromium steel for the combined static tension and repeated bending

(The lines for the combined static and repeated tension is presented for reference)

張繰返曲げ動クリープ強度推定のための上述の 考え方の妥当性を示すものと考えられる. Fig. 10 はさきに報告した 13 クローム鋼に関する実 験結果と上記方法による解析結果の比較であっ て, Fig. 8 と同様の表示をしている. 両者の一 致はこの場合もまず満足なものといえる.

なお，本解析は動クリープ変形のみについて 行なったものであるが，動クリープ破断につい ても適用することができる、すなわう，筆者ら が，低炭素鋼および 13 クローム鋼について行 なった引張圧縮動クリープ試験結果によると， 破断に関する等価静応力は变形に対する等価静 応力とほとんど同一であって，このような場合 には上記解析結果は破断強度に対しても適用し うる.

\section{6. 結言}

静クリープ試験結果より引張繰返曲げ動クリープ強 度の推定を行なうための解析的基礎を固めることを目 的として，低炭素鋼について引張繰返曲げ動クリープ 試験と試験後の試験片の残留応力測定を行ない，同時 に試験片断面内の平均応力の分布を考虑して解析を行 なった. その結果によると等価静応力が断面全体にわ たって一様であるとして計算した動クリープ強度は実 験結果との満足な一致を示し, また, 残留応力の計算 結果も測定結果とほぼ一致して, 解析の基礎とした考 え方の妥当性を示している. なお，本解析方法を既報 の 13 クローム鋼についての実験結果に適用して満足 な結果を得た．以上より本解析方法を用いることによ り, 静クリープ試験結果あるいは引張圧縮動クリープ 
試験結果より引張繰返曲げ動クリープ強度の推定が可 能であるといえる。なお, 本解析結果は動クリープ破 断の場合に適用できる。

終りに本実験を行なうにあたり，立命館大学学生浅 田秋彦, 奥村忠生の両君の協力を得たことを付記して 謝意を表する。

\section{参考文 献}

1）平, 田中, 小寺沢, 田中, 藤田, 機战学会諭文集, 25, 151, 163 (昭34)

2）平，小寺沢，小沢，鈴木，機械学会関西支部第 34 期定特総会满 演会（昭 $34-3 ）$ 飞おいて講演

3) 平, 田中, 小寺沢, 井上, 機战学会諭文集, $25,151,148$ (昭34)

4) 西原, 平, 田中, 村田, 林料試験, 5, 34, 410 (昭31)

5) 平, 村上, 材料試験, 7, 62, 591 (昭33)

6) 西原, 平, 岩田, 機械学会論交集, 13, 45, 119 (昭22)

7) 平, 田中, 小寺沢, 日本機战学会第 36 期通常総会講演会 (昭34) とおいて請演

\section{有 機 材 料}

\section{ポリマーの配向および複屈折に関する理論}

(Theory of Orientation and Double Refraction in Polymers) E.F. Gurnee,

J. App. Phys., Vol. 25, No. 10, pp. 1232 1240 (Oct. 1954) 図16, 表 2

糸からまり状自由分子の配向度が，ポリマーの両端 距離に比例すると考え，原子価角によるのこぎり歯状 分子の両端距離を配向度 $100 \%$ とする. ポリスチロー ルについて，そのメチレン結合分子が完全に配向し， フェニール基が自由回転, および拘束回転する場合に ういて, 平均分極率の差 $\left(\alpha_{z}-\alpha_{x}\right)$ を主鎖との関係は 考慮せずフェニール基の主分極率 $\alpha_{1}, \alpha_{2}, \alpha_{3}$ から計算 してある. 複屈折率 $\left(n_{z}-n_{x}\right)$ と分極率との関係は, Lorentz-Lorenz の式を用いて計算する. 実験的測定
には配行性モノフィラメントの複屈折が一様でないと き, 繊維軸から距離 $d$ に対する分布関数 $D(d)$ を求め るには，モノフィラメントの端を円錐形，またはく さび形に切断して，それの繊維軸上の Retardationの 傾斜から計算できる.

スチロール，モノフィラメントについて，くさび形 のときの実例があげられ，議論されている.

(伊藤勝彦)

\section{ゴムおよびプラスチックスに及ぼすガンマ線照射の影響}

(Effect of Gamma Radiation on Certain Rubber and Plastics) J. W. Ryan, Nucleonics, Vol. 11, No. 8, pp. 13-15 (Aug. 1953)

長期 $\gamma$ 線の照射によるゴム，およびワ゚ラスチックス の機械的性質の変化が測定された.

試料としては，ポリエチレン，ブナーN，ネオプレ ン, 天然ゴム, チオコールが用いられ，機㭜的性質と しては, ASTM D 882-46 T による応力ーひずみ曲 線, Durometer “A” seale による硬度試験と, さ
らに特殊圧縮試験も試みられている。平均フラックス 10 in photors $/ \mathrm{cm}^{2} / \mathrm{sec} 6$ 個月に及ぶ照射と未照射の ものが比較された。

r線の照射の結果は，いずれのポリマーもだいたい 弾性係数が増大し, 硬くなり, 塑性流れがおこりがた くなっている.

(伊藤勝彦) 